\title{
Cuba's Agricultural Markets ${ }^{1}$
}

José Alvarez ${ }^{2}$

On October 28, 2000, U.S. President Bill Clinton signed the Trade Sanctions Reform and Export Enhancement Act (TSRA) which allowed U.S. firms to sell food and agricultural products to Cuba and other countries. However, the Cuban government did not purchase any of these products until December of 2001 following the devastating damage caused by Hurricane Michelle to important agricultural areas in November of that year.

Cuban purchases from U.S. firms amounted to $\$ 4.319$ million in 2001, \$138.635 million in 2002, and $\$ 256.9$ million in 2003. Cuba became the 35th most important food and agricultural export market for the United States in 2003, up from last (226th) in 2000. Actual purchases and pending contracts in the first-half of 2004 are at a pace to move Cuba into the top 20 most important markets of U.S. food and agricultural exports. Furthermore, because current U.S. legislation requires that all Cuban purchases from the United States must be conducted on a cash basis, the lack of credit risk associated with these sales makes Cuba one of the most attractive export markets for U.S. firms.

Anticipating changes in U.S.-Cuba trade relations, the Food and Resource Economics
Department at UF/IFAS initiated a research initiative on Cuba in 1990, including a 1993 collaborative agreement with the University of Havana, which has lasted to this day. (Most of the resulting publications can be found at http://www.cubanag.ifas.ufl.edu). We reiterate that our role as investigators is to provide the best available information and analyses from which rational decisions can be made. The reports included in this series intend to address the increasing level of interest in the Cuban market for food and agricultural products among U.S. firms and to assist them in becoming more familiar with that market. The complete list of documents in this series can be found by conducting a topical search for "Cuba" at http://edis.ifas.ufl.edu, or under

"Additional Information" at the end of this document.

\section{Introduction}

Soon after the Basic Units of Cooperative Production (Unidades Básicas de Producción Cooperativa, UBPCs) were established, it became obvious to the Cuban leadership that, to increase agricultural production in the recently created cooperatives and other agricultural units, a change in the incentive policy was urgently needed. The idea of reopening free peasant markets, like the ones

1. This is EDIS document FE488, a publication of the Department of Food and Resource Economics, Florida Cooperative Extension Service, UF/IFAS, University of Florida, Gainesville, FL. Published July 2004. Please visit the EDIS website at http://edis.ifas.ufl.edu.

The author would like to thank the University Press of Florida (http://www.upf.com) for permission to reproduce material from the book Cuba's Agricultural Sector (Alvarez, 2004).

2. José Alvarez, Professor, Department of Food and Resource Economics, Everglades Research and Education Center, Belle Glade, FL, Florida Cooperative Extension Service, UF/IFAS, University of Florida, Gainesville, FL.

The Institute of Food and Agricultural Sciences is an equal opportunity/affirmative action employer authorized to provide research, educational information and other services only to individuals and institutions that function without regard to race, color, sex, age, handicap, or national origin. For information on obtaining other extension publications, contact your county Cooperative Extension Service office. Florida Cooperative Extension Service/Institute of Food and Agricultural Sciences/University of Florida/Christine Taylor Waddill, Dean. 
operating in 1980-1986, had been rejected in 1991 by the Fourth Congress of the Cuban Communist Party. But by 1994, the risk involved was less important than the scarcity of food. This fact sheet describes and evaluates the incentive system chosen: the new free agricultural markets. The new food outlets have been the motivation behind modest increases in agricultural production. But, almost a decade after their creation, food prices in these markets remain too high for the average Cuban consumer.

\section{Establishment and Organization}

On September 19, 1994, the Council of Ministers enacted Decree No. 191 establishing the agricultural markets (Mercados Agropecuarios, MA) (Pagés, 1994, p. 3). The main objectives of these markets were to increase the production levels of food intended for the population's consumption and to lower the prices of food in the black market. Both objectives aimed at facilitating access to food by the segment of the population without access to U.S. dollars. The MAs were originally organized by the Bureau of Commerce of the Administrative Councils of People's Power, who determined the number and location of these markets in each municipality. They later came under the jurisdiction of the Ministry of Internal Trade (MINCIN).

Only the surplus beyond the production agreement between the farmers and the state procurement agency can be sold at the MAs. Thus, more production means more output that will be available to be sold at prices agreed upon freely between buyers and sellers. Producers who fail to fulfill their obligations with the state but sell in the MAs are to face a penalty equal to the unfulfilled volume valued at the highest price prevailing at the MAs at the time of the violation.

The Administrative Councils supervised and controlled the functioning of the MAs according to the original regulations. The Ministries of Agriculture and Internal Trade were jointly responsible for regulating the organization and functioning of these markets. In addition, the Ministries of the Revolutionary Armed Forces, Interior, and other state central organizations, were in charge of establishing their own regulations as to how workers under their jurisdiction would participate in the MAs.

On September 30, 1994, the Ministries of Agriculture and Internal Trade signed a Joint Resolution regulating MA participation and the products to be sold at the MAs (Pagés, 1994, p. 3). The following entities and individuals or their appointed representatives were identified as participants in the agricultural markets:

- state farms and enterprises.

- non-cane basic units of cooperative production (UBPCs).

- agricultural production cooperatives (CPAs).

- farms under the Working Youth Army (EJT).

- cooperatives of credit and services (CCSs) representing their members.

- small farmers.

- budgeted enterprises and units that produce in their areas for self-consumption.

- producers in areas given for family self-consumption.

- producers in yards and small parcels.

The following products were excluded from the agricultural markets: bovine, buffalo, and equine meat; fresh milk; coffee, tobacco, cocoa, and their derivatives; and rice from the agro-industrial complexes (which would be entirely contracted with the state). The sale of some of these products, however, could be authorized in certain periods and territories.

For a description of the structural characteristics of the MAs during the first 15 days of operation and the differences between the MAs and the MLCs as they appear in Alvarez and Messina (1996), please visit: http://lanic.utexas.edu/la/ca/cuba/asce/cuba6/ 28alvmess.fm.pdf. 


\section{Performance}

\section{Early Years}

It is difficult to measure the performance of the MAs in the early stages. Torres and Pérez (1994, pp. 39-41) report a series of statements from both buyers and sellers about the benefits, early performance, and problems. They range from satisfaction to complaints about high prices.

The first specific positive impact of the MAs was the lowering of prices that had prevailed in the black market (Scarpaci, 1995, p. 82). For example, the price of pork fell from its 75 pesos per pound black market price in June of 1994 to 45 pesos per pound in the MA in January of 1995. Similarly, during the same period, rice prices fell from around 50 pesos per pound to about 7 to 10 pesos per pound and cassava prices fell from 15 pesos a pound to about 2 to 3 pesos (Deere, 1995, p. 16). However, prices remained high relative to the purchasing power of the average consumer. Quantities sold remained relatively stable, with independent farmers appearing to control the highest percentage of most of the commodities sold in the markets, except for banana.

Perhaps the most important contribution of the MAs to the Cuban economy in general (in addition to a series of fiscal measures implemented for that purpose) was the depreciation of the U.S. dollar in relation to the Cuban peso. Deere (1995) states that the dollar reached a peak of 120 pesos in the black market in July of 1994. By the following June, the dollar was valued at between 30 to 35 pesos (p. 17). In the spring of 1996, the exchange rate of the dollar had declined to between 21 and 23 Cuban pesos, where it remained until the end of 2001, when it increased again to between 26 and 27 pesos.

There were, of course, several other complex and varied reasons for the appreciation in value of the Cuban peso. During the period under consideration, the availability of Cuban pesos declined while the amount of U.S. dollars in circulation increased. The decrease in available pesos was the result of several factors, including labor force rationalization (which resulted in salary contraction and salaries being paid in pesos), opening free industrial markets, and a sound governmental program for reducting the national deficit.

On the other hand, the relative increase in U.S. dollars was the result of forces, including increased remittances from relatives living abroad (following the 1994 rafter crisis) and increased employment generated in the dollar sector of the Cuban economy.

In 1995, hardly one year after their opening, the 254 Cuban agricultural markets sold over 20,000 tons of agricultural and meat products valued at 1,716 million Cuban pesos. That volume represented $25-30 \%$ of total production sold to the population. In addition, the markets generated more than 75 million pesos for the national budget from renting space and almost 134 million pesos from taxes paid by the sellers (Mercados, 1996, p. 10).

\section{Subsequent Years}

The scarce and relatively dispersed information collected in the early years of the agricultural markets improved with the systematic data collection carried out by agencies such as the National Statistical Office (ONE) and the U.S.-Cuba Trade and Economic Council (USCTEC). Those data are important in examining issues such as regional differences in prices and quantities sold in the MAs.

Data collected by the USCTEC allow comparing prices in the MAs in Havana, Camagüey (500 kilometers east of Havana), and Santiago de Cuba (850 kilometers east of Havana). Data include prices for 1999 and 2000. A total of 156 complete observations were obtained to compare the prices of 30 food items in these three markets. For each year separately, prices in the three locations were ranked 1,2 , or 3 (from highest to lowest) and the same number when they were equal. The numbers then were added for each year and each city. Needless to say, an inverse relationship between price and index is pre-determined (i.e., the lower the index is, the higher the price is, and vice-versa). This ad hoc procedure, which claims no statistical value, was necessary because a weighted index was not possible since quantities purchased were not reported.

For 1999, the index numbers were 30 for Havana, 52 for Santiago de Cuba, and 59 for 
Camagüey. For 2000, the corresponding figures were 31 for Havana, 49 for Santiago de Cuba, and 65 for Camagüey. It is interesting that the numbers were so close for both years and that the numbers for all three cities fell in the same order for both years. Therefore, the conclusion is that there appears to be regional differences in the pricing of agricultural and meat products in the MAs in different geographical areas of the country, with prices in Havana being higher than in the rest of the island. The latter makes economic sense since more people (about 2.4 million) live in the Ciudad de la Habana province and have a higher purchasing power. Higher prices in Havana's MAs are the main reason for attracting sellers from nearby towns and other provinces.

Prices without some measure of volume of sales do not say much about the relative importance of the MAs. Faced with high prices in the MAs, the Cuban government created another type of agricultural market in 1998 that sold at the maximum top prices. They were placed under the jurisdiction of the Ministry of Agriculture. The original idea was to offer a wide selection of food products at prices slightly lower than those at the MAs as an attempt to force MA prices down. Statistics by ONE show the relative importance of these outlets. The quantities reported are for the whole country. The comparison is important since these are the two outlets where most of the food products are sold. The data portray interesting facts. In terms of total agricultural products in 1999, the agricultural markets with maximum top prices under MINAGRI accounted for $70 \%$ of all sales in the country and the agricultural markets under MINCIN accounted for the remaining $30 \%$. In 2000, MINAGRI's outlets accounted for $79.5 \%$ and MINCIN's MAs accounted for the remaining 20.5\% (ONE, January 2000; January 2001). It is somewhat surprising that the new agricultural markets with maximum top prices have been able to surpass the MAs in a short period of time (since 1998). The quantities sold at the MINCIN's MAs reflect a wider selection than the MINAGRI's newly created agricultural markets with maximum top prices.

However, the situation is reversed for meat products only. In 1999, $85 \%$ of total meat sales in the country were made at the MAs while MINAGRI's outlets sold the remaining $15 \%$. In 2000, the MAs sold $84 \%$ and the rest was sold in the MINAGRI's agricultural markets. It is obvious that, in the case of meat products, the agricultural markets were still the dominant force in 2000 (ONE, January 2000; January 2001).

\section{Factors Limiting Supply in the MAs}

Many factors conspire against an ample supply of food products in the agricultural markets. The ones enumerated by Nova González in 1995 were still true in 2000. They include both exogenous and endogenous factors:

- the very high food product delivery commitments that CPAs and UBPCs have with the state.

- the prohibition against sugarcane UBPCs (with self-provision plots) participating in the MAs.

- the prohibition of livestock UBPCs selling beef, milk, and related products.

- the prohibition of rice UBPCs and citrus UBPCs selling their main products.

- the prohibition of UBPCs selling coffee, potatoes, cacao, and eggs.

- the restrictions faced by all UBPCs (autonomy is the most important one) which conspire against the attainment of higher levels of production.

In addition to the former, other factors work to keep prices high in the MAs. They include, among others:

- the inefficiencies that characterize state farms and UBPCs, including low yields and many unprofitable units, leading to high production costs, which translate into high prices at the MAs.

- the dual monetary system and access to U.S. dollars by a small segment of the population who can afford to pay high prices. 
- the very large money supply, including both money in circulation and in savings accounts.

- the high prices in the so-called dollar stores which are usually used as the benchmark.

- sellers paying taxes at beginning of the day to keep prices high if they have not sold a significant amount to make a reasonable profit at the end of the day.

- oligopolistic practices which create a limited market by the few sellers participating who tend to lower expenditures for transportation, taxes, and warehousing.

To demonstrate the extent to which prices are sticky and do not decline in the agricultural markets, the national average prices of eight commodities (sweet potato, taro, pumpkin, rice, papaya, lamb, bean, and garlic) were selected from the opening of the agricultural markets until 2000. Three of these products (lamb, garlic, and bean) experienced a sharp decrease in the first two years after the establishment of the MAs but remained high afterwards. Two other commodities (rice and taro) showed slight decreases in the first two years but almost a flat line afterwards. The remaining three products (sweet potato, pumpkin and papaya) remained very stable during the seven years of the study period.

One final comment related to the supply of food products in the agricultural markets is in order. The original law established that cooperatives and independent farmers can only sell in these markets if, and only if, they have fulfilled their commitments to the state. This means that they can sell up to $20 \%$ of their production quota and, if the quota is fulfilled, they can sell $20 \%$ of their surplus (25\% in 2004). Those figures mean that what is sold in the agricultural markets is roughly $20 \%$ of the country's total (quota and surplus) production, leaving $80 \%$ for the rationed market and other specific outlets. It is obvious that, even when one accounts for shipments to other outlets (tourist sector, hospitals, schools, dollar stores, etc.), the quantities sold at the MAs are higher than $20 \%$ of the total production, assuming that everybody fulfilled the quota obligation.
The Bi-Weekly Information About Cuba published by the magazine correspondent in Havana of the Economics Press Service (EPS, 1995, p. 6) points out that, from October of 1994 through March of 1995 , these markets sold only $19 \%$ of the total tons of agricultural products distributed to the population although their variety was wider than what was sold in the state-rationed stores. It is unclear whether the news is based on official statistics or just a "guesstimate" derived from what these markets are supposed to sell. Anyway, since most of the products available at the MAs are conspicuously absent from the rationed stores, in both quantity and quality, the question then arises about the whereabouts of the quota (80\%) that was supposed to be delivered to Acopio.

\section{References}

Alvarez, José. 2004. Cuba's Agricultural Sector. Gainesville, FL: University Press of Florida.

Deere, Carmen Diana. 1995. The New Agrarian Reforms. NACLA Report on the Americas 29 (2, September-October): 13-17.

EPS. 1995. Agricultura: Mercado Agropecuario no Disparó la Producción de Alimentos. Economics Press Service 8, April 15, p. 15.

Mercados Agropecuarios Vendieron \$1,716 Millones. 1996. Business Tips on Cuba 3 (3, March): 10 .

Nova González, Armando. 1995. Mercado Agropecuario: Factores que Limitan la Oferta. Cuba: Investigaciones Económicas 3 (October): 63-72.

Nova González, Armando. 2000. Mercado Agropecuario: ¿Por Qué no Bajan los Precios? Economics Press Service 13 (15, August): 25.

ONE. Oficina Nacional de Estadísticas. 2000. Ventas en el Mercado Agropecuario, Enero Diciembre 1999, Ciudad de la Habana ( January).

ONE. Oficina Nacional de Estadísticas. 2001. Ventas en el Mercado Agropecuario, Enero Diciembre 2000, Ciudad de la Habana ( January). 
Pagés, Raisa.1994. Mercado Agropecuario:

Decreto y Resolución. Granma, September 21, pp. 1, 3.

Scarpaci, Joseph L.1995. The Emerging Food and Paladar Market in Havana. Cuba in Transition 5: 74-84.

Torres, Cary, and Niurka Pérez. 1994. Mercado Agropecuario Cubano: Proceso de Constitución. Economía Cubana-Boletín Informativo No. 18, Centro de Investigaciones de la Economía Mundial, Ciudad de la Habana (November).

USCTEC. United States-Cuba Trade and Economic Council. Weekly issues. Economic Eye on Cuba. New York.

\section{Additional Information}

Below is a list of the fact sheets in this series on Cuban Agriculture. They can be accessed by clicking on the highlighted links:

- FE479 - Cuban Agriculture Before 1959: The Political and Economic Situations

- FE480 - Cuban Agriculture Before 1959: The Social Situation

- FE481 - Transformations in Cuban Agriculture After 1959

- FE482 - Overview of Cuba's Food Rationing System

- FE483 - The Issue of Food Security in Cuba

- FE484 - Acopio: Cuba's State Procurement and Distribution Agency

- FE485 - Antecedents of the Cuban Agricultural Policies of the 1990s

- FE486 - Chronology of Cuban Reform Policies with Emphasis on Agriculture, 1993-1995

- FE487 - Cuba's Basic Units of Cooperative Production
- FE488 - Cuba's Agricultural Markets

- FE489 - Environmental Deterioration and Conservation in Cuban Agriculture

- FE490 - The Potential Correlation between Natural Disasters and Cuba's Agricultural Performance 